\title{
PENDIDIKAN PESANTREN MENURUT CAK NUR DAN YUDIAN WAHYUDI
}

\author{
Yan Yan Supriatman \\ Mahasiswa Pascasarjana UIN Sunan Kalijaga \\ e-mail: yanz_bima@yahoo.com
}

\section{Abstrak}

Pesantren adalah salah satu lembaga pendidikan tertua yang ada di Indonesia, dan merupakan lembaga yang bisa dikatakan merupakan wujud proses wajar perkembangan sistem pendidikan nasional. Kyai, santri dan ada masjid serta santri yang tinggal menetap di lingkungan pesantren menjadi kompenen dan syarat sehigga bisa dikatakan sebagai sebuah pesantren. Dalam penelitian ini mengkaji tentang bagaimana konsep pendidikan pesantren menurut Cak Nur dan Yudian Wahyudi dengan eksistensinya di Era Modern sekarang. Fokus kajian dikaji yang terdiri kurikulum, metode pengajaran yang digunakan, materi ajar, sistem sebagai sebuah lembaga pendidikan dan pengaruh kyai serta peran para santri. Dalam memperoleh data, penelitian ini menggunakan metode kualitatif dengan pendekatan library research yang kemudian data di analisis dengan cara komparatif. Diantara hasil penelitian yang didapat adalah masing-masing konsep pesantren baik oleh Cak Nur maupun Yudian Wahyudi memiliki kelebihan tersendiri. Konsep pesantren yang oleh Cak Nur hanya bersifat teoritis saja karena sampai sekarang Cak Nur belum memiliki pesantren. Sedangkan konsep pesantren oleh Yudian Wahyudi selain berguna secara teoritis juga telah diaplikasikan ke dalam pesantren yang dimilikinya sendiri yang terletak di daerah Yogyakarta. Namun kedua tokoh tersebut sama-sama pernah menimba ilmu di pesantren dan sama-sama lulusan salah satu Universitas terkemuka di luar negeri

Kata kunci: Pesantren, konsep, kurikulum dan system

\section{Pendahuluan}

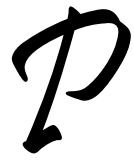

esantren telah berkiprah dalam dunia pendidikan di Indonesia dan memberikan sumbangsih yang sangat berpengaruh terhadap perkembangan bangsa, khususnya secara ideologi dan pola pikir. Banyak orang-orang besar yang lahir dari pendidikan pesantren, sebut saja ulama berkelas dunia yaitu 
syekh Nawawi al-Bantani, Wahid Hasyim yang pernah menjadi menteri agama, bahkan anaknya, Abdurrahman Wahid (Gus Dur) yang pernah menjadi presiden Indonesia dan banyak lagi para tokohtokoh besar lainnya. Namun saat ini, pesantren hampir tergerus oleh pesatnya perkembangan zaman dan tingginya arus ilmu teknologi. Pesantren tidak lagi mengambil perannya seperti halnya lima sampai sepuluh dekade sebelumnya dengan produk-produk unggul yang dihasilkan oleh dunia pesantren sangat berpengaruh dan memainkan perannya sebagai lembaga pendidiakan. Dunia modern sekarang menuntut pesantren untuk berbenah dalam hal sistem, programnya, dan kurrikulum yang sudah dianggap tidak sesuai dengan kebutuhan, agar pesantren sebagai salah satu lembaga pendidikan tertua di Indonesia tidak dijadikan sebagi salah satu fosil sejarah karena kalah saing dengan lembaga-lembaga pendidikan modern.

Berangkat dari diskursus di atas, membuat para tokoh di Indonesia khususnya tokoh yang memang pernah menimba ilmu di Pesantren seperti Cak Nur yang pernah menimba ilmu di Pesantren Darussalam Gontor dan Yudian Wahyudi pernah meniba ilmu di salah satu pesantren di daerah Tremas memberikan perhatiannya kepada perkembangan pesantren di Masa depan. Oleh sebab itu, selanjutnya tulisan ini akan membahas tentang bagaimana konsepkonsep pesantren yang ideal untuk masa depan dari sudut pandang Cak Nur dan Yudian Wahyudi.

\section{Biografi Cak Nur dan Yudian Wahyudi}

Sebelum kita akan membahas apa dan bagaimana itu pesantren dalam kerangka teori dan konsep menurut Cak Nur dan Yudian Wahyudi, terlebih dahulu akan dibahas bagaimana latar belakang dan biografi kedua tokoh di atas. Cak Nur begitulah akrabnya beliau dipanggil yang nama aslinya adalah Nurkholis Majid, lahir di Jombang, Jawa Timur 17 Maret 1939. ${ }^{1}$ Sedangkan Yudian Wahyudi

${ }^{1}$ Nurkholis Majid, Bilik-Bilik Pesantren: Sebuah Potret Perjalanan (Jakarta: Paramadina, 1997), 144. 
lahir di Balikpapan pada tahun $1960 .^{2}$ Yudian Wahyudi lebih muda 21 tahun dibandingkan dengan Cak Nur. Kalau dilihat dari kisaran umur para peserta didik di Sekolah ataupun di Kampus saat ini, bisa disimpulkan bahwa ketika Yudian Wahyudi baru lahir di Balikpapan, Cak Nur sudah duduk di bangku kuliah.

Dilihat dari belakang pendidikannya, Cak Nur dengan Yudian Wahyudi sama-sama mengenyam pendidikan di dunia pesantren. Menurut penulis, pesantren menjadi lembaga pendidikan yang sangat berpengaruh pada perkembangan dan prestasi akademik Cak Nur dan Yudian Wahyudi. Cak Nur menjadi santri di Pesantren Gontor-Ponorogo dan lulus pada tahun $1960^{3}$, sedangkan Yudian Wahyudi menjadi santri di Pesantren Termas-Pacitan (1973-1978) dan Pesantren al-Muawwir-Krapyak Yogyakarta (1978-1979). ${ }^{4}$ Setelah lulus dari pesantren, Cak Nur dan Yudian Wahyudi samasama melanjutkan jejang pendidikannya di UIN. Cak Nur melanjutkan pendidikannya di UIN Syarif Hidayatullah ${ }^{5}$ Jakarta pada Fakultas Sastra dan Kebudayaan yang lulus pada tahun 1968. Meraih gelar Doktor dari Universitas Chicago, AS (1984) dengan disertasi Ibn Taymiyya on Kalam and Falasifa. ${ }^{6}$

Sedangkan Yudian Wahyudi melanjutkan pendidikannya di UIN Sunan Kalijaga7 Yogyakarta pada Fakultas Syari'ah dan Hukum (1982 dan 1979) dan di UGM pada Fakultas Filsafat (1986). Mengambil program M.A. Islamic Studies di McGill University, Montreal, Kanada tahun 1993 dengan tesis: Hasbi's Theory of Ijtihad in the Context of Indonesia Figh. Dan melajutkan studinya dengan mengambil Ph.D. Islamic Studies, McGill pada tahun 2002 dengan

${ }^{2} Y$ udian Wahyudi, Dari McGill ke Oxford: Bersama Ali Shari'ati dan Bint al-Shati (Yogyakarta: Pesantren Nawesea Press, 2014), 91.

${ }^{3}$ Nurkholis Majid, Bilik-Bilik Pesantren.., 144.

${ }^{4} Y$ udian Wahyudi, Dari McGill ke Oxford.., 91.

${ }^{5}$ Ketika Cak Nur sedang kuliah di sana, namanya belum menjadi UIN Syarif Hidayatullah.

${ }^{6}$ Nurkholis Majid, Bilik-Bilik Pesantren.., 144.

${ }^{7}$ Sama dengan UIN Syarif Hidayatullah Jakarta ketika Cak Nur kuliah di sana. UIN Sunan Kalijaga Yogyakarta ketika Yudian Wahyudi kuliah di sana masih belum berpindah nama menjadi UIN. 
disertasi yang berjudul: The Slogan 'Back to the Qur'an and the Sunna': A Comparative Study of the Responses of Hasan Hanafi, Muhammad 'Abid al-Jabari and Nurcholis Majid. ${ }^{8}$ Sementara dari sisi pengalaman dan prestasi secara dalam organisasi, Cak Nur Ketua umum HMI dua periode (1966-1971) Presiden Persatuan Mahasiswa Islam Asia Tenggara (1967-1969); wakil Sekjen IIFSO (International Islamic Federation of Students Organisation); Pemimpin Umum majalah Mimbar Jakarta (1971-1974); Directur LSIK Jakarta (1973-1976); Directur Lembaga Kebijakan Islam Samanhudi Jakarta (1974-1992); Fellow dalam Eisenhover Fellowship (1990). Sekarang ${ }^{9}$ menjadi ketua dan sekaligus pendiri Yayasan Wakaf Paramadina, anggota Komnas HAM RI, dan dosen program Pascasarjana IAIN Jakarta. ${ }^{10}$

Sedangkan Yudian Wahyudi menjadi Ketua Persatuan Mahasiswa Indonesia-Kanada (Permika)-Montreal (1997), Presiden Pendiri Indonesia Academic Society (Montreal, 1998-199), Angsgota Middle East Studies Asosiation (sejak 1997), Anggota Amerikan Academy of Religion (sejak 1998), Pendiri Pesantren Nawesea (Center of Study of Islam in North America, Western Europe and Shouteast Asia) (2006), Kepala Pusat Penelitian dan Pengabdian Masyarakat Universitas Sains al-Qur'an Jawa Tengah di Wonosobo (2006-2010), Wakil Rois Syuriah PWNU DIY (2007-2011), Dekan Fakultas Syariah dan Hukum UIN Sunan Kalijaga (2007-2011), Ketua Tim Seleksi Calon Anggota Komisi Pemilihan Umum DIY (2008), dan Asisten Deputi Bidang Bimbingan Umat Beragama, Pendidikan Agama dan Keagamaan Kementrian Koordinator Bidang Kesejahteraan Rakyat Republik Indonesia (2011-2014). ${ }^{11}$

Karya-karya Cak Nur yang sudah diterbitkan antara lain: Khazanah Intelektual Islam (Jakarta: Bulan Bintang, 1986), Islam Kemodernan dan Keindonesiaan (Bandung: Mizan, 1988), Islam

\footnotetext{
${ }^{8}$ Yudian Wahyudi, Dari McGill ke Oxford.., 91.

"'Sekarang" maksudnya di sini adalah ketika buku Bilik-Bilik Pesantren yang dijadikan referensi oleh penulis dicetak pada tahun 1997.

${ }^{10}$ Nurkholis Majid, Bilik-Bilik Pesantren.., 144.

${ }^{11}$ Yudian Wahyudi, Dari McGill ke Oxford.., 95-96.
} 
Doktrin dan Peradaban, Sebuah Telaah Kritis tentang Masalah Keimanan, Kemanusiaan, dan Kemodernan (Jakarta: Paramadina, 1992), Islam Kerakyatan dan Keindonesiaan (Bandung: Mizan, 1993), Pintu-pintu Menuju Tuhan (Jakarta: Paramadina, 1994), Islam Agama Kemanusiaan, Membangun Tradisi dan Visi Baru Islam Indonesia (Jakarta: Paramadina, 1995), Islam Agama Peradaban (Jakarta: Paramadina, 1995), Kaki Langit Peradaban Islam (Jakarta: Paramadina, 1997), Tradisi Islam, Peran dan Fungsinya dalam Pembangunan di Indonesia (Jakarta: Paramadina, 1997), Masyarakat Religius (Jakarta: Paramadina, 1997), Perjalanan Religius 'Umroh dan Haji (Jakarta: Paramadina, 1997), Bilik-Bilik Psantren (Jakarta: Paramadina, 1997). ${ }^{12}$

Demikian pula dengan Yudian Wahyudi telah menerbitkan lebih dari 52 terjemahan buku filsafat dan keislaman dari bahasa Arab, Inggris dan Prancis ke dalam bahsa Indonesia (plus Inggris ke Arab), menerjemahkan sejumlah makalah dan antologi berbahsa Indonesia, diantaranya: Ushul Fikih versus Hermeneutika: Membaca Islam dari Kanada dan Amerika (Pesantren Nawesea Press: edisi perdana, 2006), Al-Asmin: A Pocket Dictionary of Modern Terms: Arabic-EnglishIndonesian (ditulis tahun 1991; Pesantren Nawesea Press, 2006), Maqasid Syariah dalam Pergumulan Politik: Berfilsafat Hukum Islam dari Harvard ke Sunan Kalijaga (Pesantren Nawesea Press: edisi perdana, 2006), Jihad Ilmiah: Dari Termas ke Harvard (Pesantren Nawesea Press: edisi perdana 2007, edisi ke tiga 2009), Gerakan Wahabi di Indonesia: Dialog dan Kritik, Editor (Pesantren Nawesea Press, 2009), Islam: Percikan Sejarah, Filsafat Politik, Hukum, dan Pendidikan (Pesantren Nawesea Press, 2010), Dinamika Politik “Kembali kepada al-Qur'an dan Sunnah" di Mesir, Maroko, Indonesia. Alih bahasa: Saifuddin Zuhri (Pesantren Nawesea Press, 2010), Perang Diponegoro: Tremas, SBY, dan Ploso (Jakarta: Komenko Kesra, 2012), Jihad Ilmiah Dua: Dari Harvard ke Yale dan Priceton (Pesantren Nawesea Press, 2013). ${ }^{13}$

${ }^{12}$ Nurkholis Majid, Bilik-Bilik Pesantren.., 144.

${ }^{13}$ Yudian Wahyudi, Dari McGill ke Oxford.., 92. 
Lebih dari itu, karya tulis ilmiah kedua tokoh Islam Indonesia tersebut juga termuat baik secara lokal maupun internasinal seperti; Cak Nur yang ditulis dalam bahasa Inggris: "The Issue of Modernization among Muslimsin Indonesia; From a Participant's Point of View" (dalam Gloria Davies [ed.]), What is Modern Indonesian Culture? (Athens, Ohio, University of Ohaio Southeast Asia Studies, 1979), "Islam in Indonesia: Changes and Opportunities" (dalam Cyriac K. Pullapilly [ed.]), Islam in the Contemporary World (Notre Dame, Indiana, Cross Roads Books, 1980). ${ }^{14}$ Begitu pula dengan Yudian Wahyudi tidak kalah menterengnya dengan karya-karyanya dalam publikasi internasional, diantaranya: "Ali Shari'ati and Bint al-Shati on Free Will: A Comparation", terbit dalam Journal of Islamic Studies (Oxford University Press, 1998), "The Debate about the Sarfa: Pro and Againts", terbit dalam The Islamic Quarterly (London, 2002), "Arab Responses to Hasan Hanafi's Muqaddima fi 'ilm al-Istighrab [Introduction to the Science of Occidentalism]", terbit dalam The Mulem World(Connecticut, USA, 2003), "The Epistemologhy of Al-Munqidh min al-Dalal [al-Ghazali's Deliverer from the eror]", terbit dalam The Islamic Quarterly (London, 2003), Is Islamic Law Secular? A Critical Study of Hasan Hanafi's Legal Philosophy (Pesantren Nawesea Press, 2007), Hasby's Theory of Ijtihad in The Context of Indonesian Figh (Pesantren Nawesea Press, 2007), Islam and Nasionalism: A Political Adventure of Maulana Abdul Kalam Azad (Pesantren Nawesea Press, 2007), Hasan Hanafi, Muhammad 'Abid al-Jabiri and Nurcholis Majid on the Slogan "Back to the Qur'an and the Sunna" (Fakultas Syariah Press, 2009), The Slogan "Back to The Qur'an and the Sunnah" as the Ideas Solution to the Decline of Islam in the Modern Age (1774-1974) (Pesantren Nawesea Press, 2007), Interfaith Dialogue form the Perspective of Islamic Low (Edisi Inggris dan Indonesia). ${ }^{15}$

${ }^{14}$ Nurkholis Majid, Bilik-Bilik Pesantren.., 144.

${ }^{15}$ Dan masih banyak lagi karya-karya yang lainnya, baik yang sudah diterbitkan maupun karya-karyanya yang siap untuk diterbitkan termasuk karyanya dalam bahasa Jerman. Selanjutnya lihat, Yudian Wahyudi, Dari McGill ke Oxford: Bersama Ali Shari'ati dan Bint al-Shati (Yogyakarta: Pesantren Nawesea Press, 2014), 93-94. 


\section{Konsep Dasar Pesantren Menurut Cak Nur dan Yudian Wahyudi}

Dari segi historisnya, pesantren tidak hanya identik dengan makna keislamannya, tapi juga mengandung makna keaslian Indonesia (indigenous). Sebab, lembaga yang serupa dengan pesantren telah ada sejak zaman Hindu-Budha. ${ }^{16}$ Menurut YudianWahyudi, pesantren adalah sebuah lembaga pendidikan Islam yang "berpengaruh" dalam perkembangan bangsa Indonesia yang bermula sejak Perang Diponegoro. Menurutnya, untuk memperbaiki bangsa Indonesia, perbaiki dulu pendidikan mayoritasnya. Karena mayoritasnya adalah Islam, maka perbaikilah pendidikan Islam. Untuk memperbaiki umat Islam, maka perbaiki dulu mayoritasnya. Karena mayoritasnya adalah NU, maka perbaiki dulu pendidikan NU, perbaiki dulu jantungnya yaitu pesantren. ${ }^{17}$

Menurut Cak Nur, seandainya Indonesia tidak mengalami penjajahan, mungkin sistem pendidikanny akan mengikuti jalurjalur yang ditempuh oleh pesantren-pesantren terssebut. Sehingga sebuah pesantren mungkin bisa menjadi seperti UGM, UI, ITB, IPB atau kampus-kampus yang sangat mentereng yang berkelas Nasional di Indonesia. Mungkin saja namanya bisa menjadi “Universitas" Termas, Krapyak, Gontor, Tebu Ireng ${ }^{18}$ dan lain-lain. Kemungkinan seperti ini dapat ditarik dengan membandingkan universitas-universitas terkemuka di Barat yang cikal bakal sistem pendidikannya berorientasi pada keagamaan. Cak Nur menegaskan, seandanya Indonesia tidak dijajah, mungkin saja pesantrenpesantren yang ada sekarang tidak berada di plosok daerah. Mungkin

\footnotetext{
${ }^{16}$ Nurkholis Majid, Bilik-Bilik Pesantren.., 3.

${ }^{17} Y u d i a n$ Wahyudi, Perang Diponegoro: Tremas, SBY dan Ploso (Jakarta: Deputi Bidang Kordinasi Pendidikan dan Agama, 2012), Edisi Perdana, h. xiii-xiv.

${ }^{18}$ Pesantren Tebu Ireng Jombang Jawa Timur didirikan pada tahun 1899 oleh K.H. Hasyim Asy'ari yang awalnya hanya memiliki 28 orang santri. Pengajaran yang diberikan lebih menitik beratkan ilmu-ilmu agama dan bahasa Arab. Yang setelah beberapa dekade kemudian Presiden Indonesia datang dari sana. Selanjutnya baca, Maksum Mukhtar, Madrasah; Sejarah dan Perkembangan (Jakarta: Logos Wacana Ilmu, 2001), 109.
} 
saja mereka berada di tengah-tengah atau di pusat kota. ${ }^{19}$

Pesantren memulai peranananya bagi perkembangan Indonesia setelah Diponegoro ditangkap Belanda, sebagian ulama dan umara pendukungnya melarikan diri ke Tremas dan mendirikan sebuah pesantren. Dan mengapa Tremas? Karena menurut Yudian Wahyudi, Termas berada di tengah-tengah pegunungan seribu (Java rocky mountains) dan Belanda dengan tekhnoliginya saat itu tidak dapat menjangkau Termas. Walaupun Diponegoro kalah secara jangka pendek, namun menang secara jangka panjang. Dari Termas itulah lahir para jendral-jendral besar yang berperang melawan Belanda seperti Jendral Sudirman, Jendral Ahmad Yani, dan banyak lagi yang lainnya. Bahkan pertama yang dipilih langsung oleh masyarakat Indonesia lahir di daerah sekitar sana yaitu Susilo Bambang Yudhoyono. ${ }^{20}$

Cak Nur berpendapat bahwa visi dan tujuan yang dibawa pendidikan pesantren sangat lemah. Tidak banyak pesantren yang mampu secara sadar merumuskan tahap rencana kerja atau program. Tidak adanya rumusan tujuan itu disebabkan adanya kecendrungan visi dan tujuan sendiri oleh seorang kiyai atau bersama-sama para pembantunya secara intuitif yang disesuaikan dengan perkembangan pesantrennya yang bisa dikatan bahwa pesatren itu merupakan hasil usaha pribadi atau individual (individual enterprise). Cak Nur beranggapan bahwa keterbatasan dari kemampuan seorang kiyai dalam bebrapa hal yang kemudian dipaksakan untuk dilaksanakan sendiri mengakibatkan perkembangan pesantren menjadi tidakmaksimal dan itu menjadi kekurangan bagi pesantren. ${ }^{21}$ Cak Nur melihat ketidak jelasan arah sasaran yang ingin dicapai pesantren lebih disebabkan oleh faktor kiyai yang memainkan peran yang cukup sentral dalam pesantren.

\footnotetext{
${ }^{19}$ Nurkholis Majid, Bilik-Bilik Pesantren.., 3-4.

${ }^{20} Y$ udian Wahyudi, Perang Diponegoro: Tremas, SBY dan Ploso (Jakarta: Deputi Bidang KordinasiPendidikan dan Agama, 2012),.. 3-7.

${ }^{21}$ Nurkholis Majid, Bilik-Bilik Pesantren.., 6-7.
} 
Hal itu memberikan dampak negatif karena kiyai memiliki keterbatasan dan kekurangan. ${ }^{22}$

Dilihat dari konteks perkembangan pendidikan pesantren, bila merujuk pada tulisan Ahmad Muhakamurrohman dalam jurnalnya "Pesantren: Santri, Kiai, san Tradisi" ia mengklasifikasi pesantren di Indonesia berdasarkan karakteristik dan tradisi terdapat dua konsep pendidikan pesantern yakni jenis pesantren dengan konsep Tradisional, dan ada pula pesantren dengan konsep Modern. Pertama, konsep pesantren Tradisional menurut hasil riset Geerzt dalam Ahmad Muhakamurrohman, dilihat adari aktivitas para santri dalam menjalani kehidupan di pesantren, misalnya; Para santri sampai masa tertentu tinggal di pondok yang menyerupai asrama biara. Mereka mendapat makan dengan bekerja di sawah milik kiai atau orang-orang Islam terkemuka lainnya dalam masyarakat itu, atau dengan bekerja sebagai pencelup warna kain, menggulung rokok, menjahit, dan ada pula yang mendapat kiriman beras dan uang dari keluarga di rumah. Kiai tidak dibayar dan para murid pun tidak membayar uang sekolah. Seluruh biaya lembaga itu dipikul oleh orang-orang yang saleh di antara umat sebagai bagian dari kewajiban membayar zakat. Adapaun ciri-ciri pesantren tradisional, yaitu pesantren yang dalam sistem pembelajarannya masih menggunakan sistem bandongan dan sorogan, begitu pula dalam materi yang diajarkan pun berasal dari kitab-kitab kuning (turats), kitab berbahasa Arab karya ulama Islam baik luar maupun dalam negeri. Pesantren besar yang hingga kini masih menganut sistem pengajaran tradisional seperti Pondok Pesantren API Tegalrejo, al Falah Ploso Kediri, Pondok Lirboyo Kediri, Pesantren Sidogiri, Pesantren Langitan, dan al-Anwar Sarang Rembang. ${ }^{23}$

Kedua, konsep pesantren Modern dapat dilihat dari kurikulum dan tradisinya, pesantren modern dapat dengan mudah dibedakan

${ }^{22}$ Yasmadi, Modernisasi Pesantren: Kritik Nurckholis Majid Terhadap Pendidikan Islam Tradisional (Ciputat: Ciputat Press, 2002), cet. I, 73.

${ }^{23}$ Lihat Ahmad Muhakamurrohman, "Pesantren: Santri, Kiai, san Tradisi" Ibda' jurnal kebudayaan Islam (Vol. 12, No. 2, Juli - Desember 2014), 112. 
dengan pesantren tradisional. Pesantren modern dalam perkembangannya memasukkan mata pelajaran umum ke dalam kurikulum pesantren. Tidakjarang, bahkan penambahan itu sampai menghilangkan karakteristik sebelumnya, atau menghegemoni tradisi serta mata pelajaran klasikal. Dari fisik, infrastruktur, dan sistem pendidikan, pesantren modern dapat dengan mudah dibedakan dari pesantren salafi atau pesantren tradisional. Bangunan-bangunan pesantren modern lebih bersih dan terawat, adanya dapur-dapur siap saji, adanya pakaian seragam, auditorium megah, lapangan olahraga, ruang pengembangan bakat dan keterampilan, hingga laboratorium bahasa. Jikalau dalam pengajian bandongan para santri dalam mengaji tidak ada kewajiban hadir, dalam pesantren modern sudah mulai menata struktur pembelajarannya melalu sistem absensi. Sistem dan pembekalan yang dirancang juga sudah sedemikian rupa, guna mempersiapkan santri menghadapi arus modernitas. Nilai yang ditanamkan pada lembaga modern ini, tak lagi hanya sebatas pembentukan karakter santri, namun sudah lebih melampaui itu. Santri tak hanya melulu bergelut dengan kitab kuning, tapi juga telah dilengkapi kurikulumnya dengan mata pelajaran seperti di sekolah umum. Di lembaga modern ini, selain dibekali materi agama dan mata pelajaran umum, para santri juga digali potensinya. Para santri kemudian diklasifikasikan sesuai dengan minat dan bakat, yang selanjutnya disebut dengan kelas fakultatif. Alumni pesantren modern biasanya mampu berdikari, meski dalam kemampuan menguasai ilmu nahwu, sharaf, dan fikih kurang begitu mumpuni. Pesantren besar yang berhaluan modern dan masih eksis hingga sekarang itu seperti Pesantren Modern Gontor yang sekarang cabangnya banyak tersebar di beberapa daerah di Indonesia. Selain Gontor, sekarang juga mulai banyak bermunculan pesantren modern baru yang penyebabnya konon karena adanya skeptisme masyarakat atas pesantren tradisional. Pesantren yang pengajarannya masih klasik dan belum memasukan pelajaran umum dianggap tidak menjanjikan masa 
depan yang cerah karena tidak adanya pengakuan sebagai sekolah formal sehingga ijazahnya belum diakui oleh pemerintah. ${ }^{24}$

Bertemali dari konsep pendidikan pesantren tersebut, menurut hemat penulis konsep pendidikan pesantren masa depan dalam pandangan Cak Nur dan Yudian Wahyudi cenderung menekankan muatan konsep pengembangan pola manajemen pesantren modern seperti Pesantren Modern Gontor. Lebih khususnya Cak Nur, menegasakan pula gambaran pesantren masa depan, menurutnya konsep pesantren masa depan dapat dianalisa dari praksis metodologi pengembangan pembelajaran di dalam pesantren, sebagaimana yang dikemukakan Mohammad Salik dalam jurnalnya "Menggagas Pesantren Masa Depan: Kritik Cak Nur atas Pola Pendidikan Tradisional" menjelaskan kritik dan ide-ide tentang pendidikan pesantren berkaitan dengan usaha-usaha pembaharuan pendidikan di pondok pesantren, Cak Nur melihat Pondok Modern Gontor, sebagai representasi pesantren masa depan di Indonesia. Pernyataan tersebut bukan tanpa dasar, menurut Cak Nur Pondok Modern Gontor juga mempunyai jiwa dan falsafah hidup yang terkenal dengan sebutan Panca Jiwa; yaitu keikhlasan, kesederhanaan, kemandirian, ukhuwah Islamiyah, dan kebebasan. Kelima jiwa ini selalu ditanamkan melalui segala gerak dan aktifitas di pondok tersebut baik oleh oleh para pengasuh dan juga para santrinya. Panca jiwa ini selalu diiringi dengan motto yang selalu berusaha untuk diterapkan yaitu: berbudi tinggi, berbadan sehat, berpengetahuan luas, dan berfikiran bebas. Motto ini tidak boleh dibolak-balik urutannya, terutama jiwa bebas, dan motto berfikiran bebas, tidak boleh didahulukan sebelum berpengetahuan luas. ${ }^{25}$

Inilah yang dikagumi oleh Cak Nur. Dalam salah satu tulisannya ia menyatakan bahwa salah satu balai pendidikan Isalam yang

\footnotetext{
${ }^{24}$ Lihat Ahmad Muhakamurrohman, "Pesantren: Santri, Kiai, san Tradisi"....,114.

${ }^{25}$ Lihat Mohammad Salik"Menggagas Pesantren Masa Depan: Kritik Cak Nur atas Pola Pendidikan Tradisional" (UIN Sunan Ampel Surabaya Email: salik_mohamad@yahoo.com diakses 20 Mei 2017), 14.
} 
liberal, yaitu Balai Pendidikan "Darussalam" di Gontor, Ponorogo Jawa Timur, mencantumkan sebagai mottonya "Berpikirah Bebas" setelah "Berbudi Tinggi, "Berbadan Sehat" dan "Berpengetahuan Luas". Di antara kebebasan perseorangan, kebebasan berfikir dan menyatakan pendapatlah yang paling berharga. Pada bagian lain Cak Nur juga menyatakan bahwa di antara salah satu motto Pondok Gontor adalah berpikir bebas. Bebas melakukan segala perilaku yang didasarkan pada pemikiran. Prinsip ini benar-benar telah membuat Pondok Gontor menjadi unik. Pesantren Gontor menduduki dua sisi yang sangat kontras, antara kebebasan dan disiplin regimenter. Ini unik sekali, dua hal yang saling kontras dapat hidup bersamasama. Tampaknya inilah yang menjadi cikal bakal dan konsep awal dari pemikiran-pemikiran pembaharuan pendidikan yang digagas oleh Nurcholish Madjid/Cak Nur. Ia menjadikan Pondok Pesantren Modern Gontor sebagai model bagi pembaharuan pendidikan pesantren di Indonesia. ${ }^{26}$

\section{Pesantren sebagai Unit Penyelenggara Pendidikan}

Cak Nur, menilai pesantren dari segi fisiknya sudah jatuh dari skala prioritas, namun yang sangat perlu ditinjau adalah dari segi non-fisiknya yang menjadi titik tolak perubahan, perkembangan, pertumbuhan, dan kemajuan yang berupa jiwa keseluruhan. ${ }^{27}$ Yudian Wahyudi sendiri dalam karya-karyanya tidak menyinggung pesantren dari segi fisik atau bangunannnya. Namun lebih kepada fungsi dari bangunan yang serba kekurangan tersebut. Seperti halnya pada asrama, Cak Nur berpendapat bahwa asrama-asrama pada pesantren sangat sempit, terlalu pendek, jendela terlampau kecil, dan pengaturannya pun tidak beraturan. Selain itu sangat minim dengan peralatan seperti ranjang atau dipan, meja, kursi, dan tempat untuk menyimpan pakaian. Dan banyak hal lain pesantren dari segi

${ }^{26}$ Lihat Mohammad Salik"Menggagas Pesantren Masa Depan: Kritik Cak Nur atas Pola Pendidikan Tradisional"....,15-16.

${ }^{27}$ Nurkholis Majid, Bilik-Bilik Pesantren.., 6. 
fisiknya terlihat sangat tidak memadai, seperti halaman, ruang belajar, tempat ibadah, dan lain-lain. Keadaan-keadaan yang seperti itu membuat pesantren tidak cocok dengan dunia modern dan tidak mampu menantang zaman (lagging behind the time). ${ }^{28}$

Sedangkan Yudian Wahyudi yang lebih melihat asrama dari sudut pandang fungsinya yang mengatakan berasrama adalah salah satu kelebihan pesantren. Karena dengan berasrama, murid di pesantren masih diatur oleh program-program yang melekat yang mendukung pelajaran di sekolah seperti belajar bersama di malam haridan yang lainnya. Hal itu berbeda dengan sekolah-sekolah umum yang tidak berasrama, ketika jam sekolah telah selesai, mereka langsung pulang ke rumah dan menyusun programnya masing-masing. Dan para murid yang berasrama tersebut biasanya datang dari daerah-daerah yang berbeda, sehingga murid lebih mengetahui budaya, adat dan karakter dari teman-temanya yang datang dari daerah yang berbeda. Hal seperti itu secara tidak langsung memberikan pesan pendidikan, bagaimana seorang siswa bisa saling toleransi dan menghargai. ${ }^{29}$

Menurut Cak Nur, pesantren akan kehilangan eksistensinya karena ketinggalan jauh dari lembaga pendidikan yang lainnya. Para kiyai di kota-kota besar sendiri telah mengalami kenaikan status sosial (pada umumnya melalui jenjang politik), mereka lebih percaya menyekolahkan anak-anaknya di sekolah umum dari pada di pesantren sendiri. Kalu perlu, mereka memasukkan anak-anaknya ke bidang-bidang paling produktif seperti ekonomi, kedokteran dan tekhnik. Sementara itu mereka "membiarkan" anak-anak desa dari orang-orang kecil tetap sekolah di pesantren. Mungkin karena massa pengikutnya akan hilang tanpa pesantren yang tradisional itu. Oleh sebab itu mereka juga masih membela adanya pesantren dan sistemsistemya yang berlaku. ${ }^{30}$ Namun Yudian Wahyudi berbeda dalam

${ }^{28}$ Nurkholis Majid, Bilik-Bilik Pesantren.., 90-91.

${ }^{29} Y$ udian Wahyudi, Perang Diponegoro..,39-43.

${ }^{30}$ Nurkholis Majid, Bilik-Bilik Pesantren..,100-101. 
menyikapi kekurangan atau kelemahan pada pesantren sebagai lembaga pendidikan terhadap perkembangan zaman (modern) terlebih dalam ilmu pengetahuan dengan membangun sebuah pesantren yang beridiri di tengah-tengah kota Yogyakarta yang berorientasi terhadap experimen scientific yaitu lebih tepatnya pesantren untuk menaklukan UN/NEM. Pesantren dengan nama Sunan Averos dijalankan dengan membayar tenaga pendidikan dari lulusan universitas-universitas terbaik di DIY secara profesional dan proporsional. Faktor pendukung pesantren Sunan Averos yang menjadi pembeda dengan pesantren yang lainnya adalah dekat dengan pusat informasi dan fasilitas olahraga. Sehingga santri Sunan Averos akan mudah mendapatkan informasi yang mereka butuhkan dalam rangka pengembangan kerohanian (spiritual-transedental), akademik, sosial, bahkan jasmaniah (fisik-medis). ${ }^{31}$

\section{Kurikulum dan Relevansi Pesantren terhadap Perkembangan Pendidikan}

Kurikulum menjadi bagian yang sangat penting dalam menentukan keberhasilan sebuah lembaga pendidikan, tak terkecuali dengan pesantren. Menurut Cak Nur, kurikulum adalah bagian yang sangat dari pada hal yang lainnya. Namun dalam konteks kurikulum pesantren sebagai salah satu lembaga pendidikan terdapat ketidak cocokan antara dunia pesantren dengan dunia luar. ${ }^{32}$

Kurikulum yang berkembang di pesantren semuanya bermuara kepada bahasa Arab, sehingga memposisikan bahasa Arab merupakan bagian dari ilum agama. Dalam hal ini Cak Nur berpendapat bahwa Nahwu-Saraf; dianggap aneh karena pelajaran gramatika bahasa (Arab) cenderung untuk dimasukkan ke dalam ilmu agama. Nahwu-saraf memang bisa diangap penting sebagai "ilmu alat" mempelajari agama yang ditulis dalam bahasa Arab, tetapi di pesantren-pesantren keadaannya sudah tidak proporsional

\footnotetext{
${ }^{31}$ Yudian Wahyudi, Perang Diponegoro..,41.

${ }^{32}$ Nurkholis Majid, Bilik-Bilik Pesantren..,93.
} 
lagi dan kurang relevan. ${ }^{33}$ Sistem pengajaran; menurut Cak Nur, sistem yang biasanya dipakai dalam pesantren ituterkenal tidak efisien. Disebabkan karena caranya yang unik dan memang khas pesantren. Sistem penjenjangan (graduation) yang tidak sistematis (sering terjadi pengulalngan), pemilihan kitab yang kurang relevan, cara membaca kitab dengan terjemahan harfiah (kata demi kata) dan seterusnya. ${ }^{34}$ Sedangkan menurut Yudian Wahyudi salah satu yang menjadi sebuah kelebihan pesantren adalah karena sistem pengajarannya dengan takror dan sorogan. Takror sebagai kegiatan pendalaman materi di malam hari ini sebenarnya jauh melampaui tradisi sekolah menengah Indonesia. Tak satupun sekolah menengah di Indonesia yang mentradisikan belajar bersamadi malam hari, kecuali sekolah berasrama. Metode sorogan juga menjadi andalan bagi pesantren dalam proses pendalaman materi, seperti halnya pada Termas yang polanya ditata berdasarkan kelas. Hal ini pula yang idungkap Yudian Wahyudi sendiri ketika kuliah di UIN Sunan Kalijagaperanah mengusulkan pola belajar sorogan kepada dosennya di setiap harinya setelah subuh, namun sang dosen kaget dan tidak siap..$^{35}$

Dari gagasan tentang pesantren yang telah dikemukakan oleh Cak Nur, beliau berpendapat bahwa ada dua kesimpulan pokok yang dapat diambil. Pertama, pesantren berhak, bahkan lebih baik dan lebih berguna mempertahankan fungsi pokoknya semula, yaitu sebagai tempat menyelenggarakan pendidikan agama. Namun dilakukan peninjauan kembali sedemikian rupa sehingga ajaranajaran agama yang diberikan kepada setiap pribadi merupakan jawaban yang komprehensif atas persoalan makna hidup dan weltanschauung Islam, selain tentu saja disertai dengan pengetahuan yang cukup kewajiban-kewajiban praktis seorang Muslim seharihari. Kedua, pesantren harus tanggap dengan tuntutan-tuntutan

${ }^{33}$ Nurkholis Majid, Bilik-Bilik Pesantren..,94

${ }^{34}$ Nurkholis Majid, Bilik-Bilik Pesantren..,94.

${ }^{35}$ Yudian Wahyudi, Perang Diponegoro..,50-54. 
hidup peserta didiknya kelak dalam kaitannya dengan perkembangan zaman. Dimana sebuah pesantren dituntut supaya membekali peserta didiknya dengan kemampuan-kemampuan nyata yang didapat melalui pendidikan atau pengajaran pengetahuan umum secara memadai. Dengan menyediakan jurusan-jursan alternatif bagi peserta didik sesuai dengan minat, bakat dan potensi ${ }^{36}$ alamiahnya masing-masing. ${ }^{37}$

Berngkat dari hal tersebut, Cak Nur menyimpulkan bahwa tujuan pendidikan pesantren adalah membentuk manusia yang memiliki kesadaran tinggi bahwa ajaran Islam merupakan weltanschuung yang bersifat menyeluruh. Dan hasil dari pendidikan pesantren diharapkan memiliki kemampuan tinggi untuk mengadakan responsi terhadap tantangan dan tuntutan hidup dalam konteks ruan dan waktu yang ada di Indonesia dan dunia (konteks abad kekinian). ${ }^{38}$ Dalam hal metode pengajaran dan ide pokok yang di tawarkan Cak Nur agar pesantren lebih baik lagi yaitu:

1. Mempelajari al-Qur'an dengan cara yang lebih sungguhsungguh dari pada yang umumnya dengan cara menitik beratkan pada pemahaman makna dan ajaran-ajaran yang terkandung di dalamnya. Dalam hal ini mungkin mirip dengan pelajaran tafsir, namun ini bisa dilakukan dengan tanpa kitab tafsir dan langung pada al-Qur'annya saja.

2. Melalui pertolongan sebuah bahan bacaan atau buku pegangan. Hal ini sangat bergantung pada kemampuan para pengajar dalam pengembangannya.

3. Memanfaatkan pelajaran lain untuk disisipi pandanganpandangan keagamaan, dan menanamkan kesadaran dan penghargaan yang lebih wajar pada hasil-hasil seni-budaya Isalam atau seni-budaya umumnya. Karena hai ini bisa

\footnotetext{
${ }^{36}$ Yang dalam Pendidikan Islam biasa disebut dengan istilah fitrah sebagaimana yang telah diberikan Allah sejak lahir.

${ }^{37}$ Nurkholis Majid, Bilik-Bilik Pesantren..,17-18.

${ }^{38}$ Nurkholis Majid, Bilik-Bilik Pesantren..,18.
} 
menumbuhkan kepekaan rohani, termasuk kepekaan rasa ketuhanan yang menjadi inti rasa keagamaan.

Menurut Cak Nur hal yang lebih penting lagi adalah, pesantren dapat mengadakan pendalaman-pendalaman pada segi lainnya pada satu tingkat yang lebih lanjut dan bersifat "takhassus", yaitu suatu keharusan mengadakan pengaturan kembali alokasi waktu dan tenaga pengajar sehingga terjadi penghematan dan intensifikasi bagi pelajaran-pelajaran lainnya. ${ }^{39}$ Semnetra menurut Yudian Wahyudi, metode yang digunakan dalam pendidikan pesantren telah tepat berada di jalurnya. Selain metode takror dan sorogan yang merupakan kelebihan dalam pendidikan pesantren sebagaimana telah disebutkan pada bagian subjudul sebelumnya, ada juga metode evaluasinya dengan ujian lisan. Menurutnya ujuan lisan tidak seperti ujian tertulis, karena dalam ujian lisan santri harus berhadapan langsung dengan guru. Dalam ujian lisan, santri dilatih untuk mengalami "kiamat ilmiah": hari perhitungan amal (transparansi dan akuntabilitas). Pandangan teologis Islam divisualkan dalam proses tanya-jawab antara guru dan murid. Guru berperan sebagai "malaikat" yang akan meminta pertangungjawaban seorang murid secara face to face dan one on one. Si murid tidak bisa mengelak, sehingga terpaksa harus belajar lebih giat untuk menyambut kiamat ilmiah tersebut. ${ }^{40}$

\section{Kekurangan dan Kelebihan Pendidikan Pesantren}

Kekurangan pesantren adalah kemampuan pesantren dalam merespon dan mengimbangi perkembangan zaman, yang ditambah dengan faktor lain yang sangat beragam, membuat produk-produk pesantren dianggap kurang siap untuk "lebur" dan mewarnai kehidupan modern apa lagi kalau dibandingkan dengan peran dari produk "pesantren" Harvard. Meskipun produk pesantren memiliki warna keagamaan biasanya memperoleh gelar sebagai kiyai, 'alim,

\footnotetext{
${ }^{39}$ Nurkholis Majid, Bilik-Bilik Pesantren..,18.

${ }^{40}$ Yudian Wahyudi, Perang Diponegoro..,57-58.
} 
ustadz atau sekedar santri, namun diukur dari keharusan-keharusan keagamaan itu sendiri masih menunjukkan kekurangan. ${ }^{41}$ Dalam hal ini, Cak Nur tidak menerangkan secara spesifik apa yang menjadi kekurangan dari dari pesantren, dia hanya mengatakan bahwa pesantren tidak merespon perkembangan zaman. Namun, Yudian Wahyudi menyebutkan dengan lebih detail bahwa kekurangan pesantren dalam perkembangan zaman sekarang itu sedikit mengabaikan "Ijazah" yang menjadi sebuah simbol bagi kemampuan dan keahlian sebuah produk lembaga pendidikan.

Lebih lanjut Yudian Wahyudi juga mengeskan, untuk kemaslahatannya sendiri, pesantren harus beradaptasi dengan lembaga pendidikan Indonesia yang lainnya yang sudah mampu melahirkan otoritas keilmuan dengan berbagai variasi dan tingkatannya (yang dalambahasa arabnya adalah ulama). Keberhasilan tersebut telah mengantarkan bangsa menuju peradaban kontemporer: masyarakat madani atau civil society. Dengan demikian, "pabrik ijazah" tidak boleh dipandang negatif dan memusuhi sekolah di masa penjajahan, namun harus diterima sebagai otoritas yang sah. Ijazah ${ }^{42}$ sebagai alat legitimasi harus mendapatkan pengakuan dari pemerintah (syahadah dari ulil amr). Dari sini pesantren, bersama-sama dengan semua lembaga pendidikan yang diakui pemerintah akan semakin memberikan sumbangsih yang sangat penting dalam rangka menyambut Indonesia Emas. ${ }^{43}$

\section{Pesantren; Continouity, Change dan Transedence}

Cak Nur memberikan gambaran konkrit dengan menganalogikan sebuah pesantren di Indonesia seperti Tebuireng di JombangJawa Timur dengan sebuah lembaga pendidikan "pesantren" Harvard yang didirikan oleh pendeta Harvard di sekitar Boston

\footnotetext{
${ }^{41}$ Nurkholis Majid, Bilik-Bilik Pesantren.., 7.

${ }^{42}$ Dari bahasa Arab yang berarti otoritasi atau pemberian wewenang.

${ }^{43} Y u d i a n$ Wahyudi, Perang Diponegoro.., 17.
} 
Amerika. Sekilas Tebu Ireng sejak awal berdirinya hingga sekarang, masih eksis sebagai pesantren, sedangkan Harvard telah menjadi sebuah Universitas terkemuka di dunia. ${ }^{44}$ Sedangkan menurut Yudian Wahyudi, pesantren-pesantren di Indonesia seperti Tebuireng atau yang lainnya tidak berkembang seperti "pesantren" Harvard di Amerika karena Harvard seminari mengembangkan experimental sciences, sedangkan pesantren di Indonesia membuang applied sciences dari kurikulumnya.. ${ }^{45}$

Cak Nur beranggapan bahwa kesenjangan waktu atau time leg memang mengandung konotasi pada posisi ketinggalan, konservatif, ataupun kolot. Namun tidak jika benar kalau keagamaan dipandang sebagai sebuah kekolotan. Universitas Harvard misalnya, relevansi keagamaan dengan perkembangan zaman sama sekali tidak meninggalkan fungsi pokok atau historis sebagai tempat pendidikan keagamaan. Itu terbukti dengan adanya bagian-bagian yang mengajarkan teologis, terdapat monumen-monumen keagamaan seperti gereja-gereja di lingkungan sekitar kampusnya, capel-capel dan koleksi barang-barang keagamaan. Bahkan Harvard tetap meneruskan peran historisnya sebagai penganut mazhab unitarianisme. Berkaitan dengan hal tersebut, bahwasannya pesantren-pesantren di Indonesia memerankan peran besar dan menentukan ruang lingkup nasional, tanpa menghilangkan esensi sebagai basis pendidikan keagamaan. Bahkan tradisi-tradisi keagamaan itu merupakan ciri khusus yang harus dipertahankan, karena itu merupakan kelebihannya. ${ }^{46}$

Lebih lanjut Cak Nur berpendapat bahwa, peta dunia sekarang ditandai dengan konflik-konflik denagn warna keagamaan. Meskipun bukan satu-satunya faktor penyebab, namun sangat banyak memainkan peran. Baik diantara penganut agama yang berbeda maupun antar sesama penganut agama tertentu dengan

${ }^{44}$ Nurkholis Majid, Bilik-Bilik Pesantren..,4.

${ }^{45}$ Yudian Wahyudi, Perang Diponegoro..,22.

${ }^{46}$ Nurkholis Majid, Bilik-Bilik Pesantren..,5. 
mazhab yang berbeda. ${ }^{47}$ Berbeda dengan Cak Nur, menurut Yudian Wahyudi bahwa orang Amerika bahkan tidak bisa memastikan sejarah John Harvard, siapa dia sebenarnya sehingga namabelakangnya diabadikan sebagai nama sebuah universitas yang telah hampir empat abad kemudian dinyatakan sebagai yang terbaik di Dunia.Experimental sciences-oriented curriculum dan ditopang dengan fondasi ekonomi yang kuat menjadi unsur terpenting dalam perkembangan Harvard. Hal di atas kemudian melahirkan revolusi industri yang meruntuhkan kekuasaan agamaagama di Dunia termasuk Islam. ${ }^{48}$ Bahkan Cak Nur beranggapan bahwa pesantren dan sistem-sistemnya memang dihadapkan pada tantangan zaman yang cukup berat. Jika tidak mampu memberi responsi yang tepat, maka pesantren akan kehilangan relevansinya dan akar-akarnya dalam masyarakat akan tercabut dengan kerugian yang bakal ditanggung. ${ }^{49}$ Menurut Yudian Wahyudi, kalau ingin merubah pesantren menjadi universitas, apa lagi yang kelas dunia seperti Harvard maka pesantren harus menjadikan experimental sciences agat dapat menghasilkan produk yang mengedepankan hard skill sebagai kurikulum inti dan sebagai bagian dari keimanan dan keislaman. ${ }^{50}$

\section{Penutup}

Pesantren dengan segala keterbatasannya, mulai tersisihkan oleh tantangan dan kebutuhan perkembangan zaman (modern) membuat Cak Nur sedikit beranggapan bahwa pesantren mulai tidak mampu memberi responsi yang tepat, akan mengakibatkan pesantren akan kehilangan relevansinya dan akar-akarnya dalam masyarakat akan tercabut dengan kerugian yang bakal ditanggung sendiri. Oleh sebab itu, untuk men-disign sebuah pesantren untuk

\footnotetext{
${ }^{47}$ Daud Rasyid, Pembaharuan Islam \& Orientalisme dalam Sorotan (Bandung: Syaamil Cipta Media, 2006), Edisi Baru, 30-31.

${ }^{48}$ Yudian Wahyudi, Perang Diponegoro..,31-33.

${ }^{49}$ Nurkholis Majid, Bilik-Bilik Pesantren..,100.

${ }^{50}$ Yudian Wahyudi, Perang Diponegoro.., 22.
} 
kebutuhan masa depan, harus diubah pola dan sistemnya yang sesuai dengan kebutuhan dan perkembangan dunia sekarang. Menurut Yudian Wahyudi, kalau ingin merubah pesantren menjadi universitas, apa lagi yang kelas dunia seperti Harvard maka pesantren harus menjadikan experimental sciencesdan bisa menghasilkan produk yang hard skill sebagai kurikulum inti sebagai bagian dari keimanan dan keislaman.

Sedangkan Cak Nur hanya memebrikan konsep dan saran untuk kebutuhan perkembangan pesantren agar tetap eksis dalam duniapendidikan, namun belum mendirikan pesantren. Sedangkan Yudian Wahyudi langsung mengaplikasikan konsep pesantren masa depan dengan mendirikan pesantren Sunan Averos di Yogyakarta yang berorientasi pada experimen sciences, bahasa (Arab dan Inggris) dan dengan program untuk menaklukan UN/NEM. Meskipun di satu sisi, ide pembaharuan pendidikan pesantren masa depan cenderung menekankan prototype Pondok Modern Gontor, menurutnya Cak Nur sebagaiama diungkap Mohammad Salik, bahwasannya pola pendidikan Pondok Modern Gontor menekankan kebebasan dalam madzhab pendidikan atau non-sektarian ditanamkan lewat pengajaran dan materi yang diajarkan. Diajarkannya usul fiqh, kitab Bidayatul Mujtahid, karya Ibnu Rusyd, jelas-jelas membantu tumbuhnya jiwa kebebasan pada diri para santri Gontor, yang itu menjadi ciri khas produk didikan Pondok Gontor. Akan baik jika itu tetap terus dipegang dan dipertahankan, karena hal itu sesuai dengan prinsip-prinsip dasar pendidikan modern yang liberal. Selain dari perbedaan-perbeaan yang tersebut ternyata kedua tokoh ini memiliki kesamaan yaitu Cak Nur dan Yudian Wahyudi adalah sama-sama pernah menimba ilmu di pesantren dan sama-sama menjadi lulusan dari salah satu Universitas terkemuka di luar negeri, sehingga konsep pesantren masa depannya dapat dijadikan acuan untuk membangun dan mengembangkan pesantren yang sesuai dengan tuntutan kondisi zaman. 
Tajdid: Jurnal Pemikiran Keislaman dan Kemanusiaan, Vol. I No. I April 2017: II3-I34

\section{Daftar Pustaka}

Ahmad Muhakamurrohman, "Pesantren: Santri, Kiai, san Tradisi" Ibda' jurnal kebudayaan Islam Vol. 12, No. 2, Juli - Desember 2014.

Majid, Nurkholis. Bilik-Bilik Pesantren: Sebuah Potret Perjalanan. Cet. I; Jakarta: Paramadina, 1997.

Mohammad Salik"Menggagas Pesantren Masa Depan: Kritik Cak Nur atas Pola Pendidikan Tradisional"UIN Sunan Ampel Surabaya Email: salik_mohamad@yahoo.com diakses 20 Mei 2017.

Mukhtar, Maksum, Madrasah; Sejarah dan Perkembangan. Cet. III; Jakarta: Logos Wacana Ilmu, 2001.

Rasyid, Daud,Pembaharuan Islam \& Orientalisme dalam Sorotan. Bandung: Syaamil Cipta Media, 2006.

Saridjo, Marwan,Cak Nur: Di Antara Sarung dan Dasi, \& Muzdah Mulia Tetap Berjilbab. Cet. II; Jakarta: Yayasan Ngali Aksara Penamadani, 2005.

Wahyudi, Yudian, Dari McGill ke Oxford: Bersama Ali Shari'ati dan Bint al-Shati. Yogyakarta: Pesantren Nawesea Press, 2014. Perang Diponegoro: Tremas, SBY dan Ploso. Jakarta: Deputi Bidang KordinasiPendidikan dan Agama, 2012.

, Jihad Ilmiah: Dari Termas ke Harvard. Yogyakarta: Pesantren Nawesea Press, 2009.

, Ushul Fikih versus Hermaneutika: Membaca Islam dari Kanada dan Amerika. Cet. VIII; Yogyakarta: Pesantren Nawesea Press, 2014).

,Maqasid Syari'ah dalam Pergumulan Politik; Berfilsafat Hukum Islam dari Harvard ke Sunan Kalijaga. Cet. IV; Yogyakarta: Pesantren Nawesea Press, 2014.

Yasmadi, Modernisasi Pesantren: Kritik Nurckholis Majid Terhadap Pendidikan Islam Tradisional. Cet. I; Ciputat: Ciputat Press, 2002. 